низм самоорганизации, вырабатываются новые, более адекватные формы социальной и политической жизни. В отличие от А.Филиппова, принципиально стоящего на позиции наблюдателя, А.Магун делает из своего анализа и практические выводы. Революция конца 1980-х - начала 1990-х годов была оборвана. Задача российского общества - продолжить ее.

Несколько особняком стояло выступление Е.Надеждиной, сфокусировавшей внимание на использовании революционной символики в массовой культуре, роке, рекламе. Резко негативный смысл слова «революция» в массовой культуре 1990-х годов Е.Надеждина объясняет тем, что понятие «революция) ассоциировалось с отвергнутым политическим строем и было «приватизировано» господствующим дискурсом. Именно поэтому оно и не употреблялось по отношению к событиям начала 1990-х годов. Современный рок, реклама, поп-арт «реабилитируют» концепт революции. За право именоваться революционерами и носителями революционности сегодня ведется все более ожесточенная борьба.

В прениях выступили С.Патрушев, В.Цымбурский, Е.Лобза, А.Антощенко и др. Е.Лобза предложила поразмышлять о замене в современном дискурсе характерных для революционных текстов начала XX в. образов «пожара» и «потопа» образом «волны». С ее точки зрения, этот новый образ существенно смягчает присущие первым двум апокалиптические мотивы.

Основной темой дисќуссии стал революционный дискурс в современной России. Согласно оценке В.Цымбурского, главное отличие нынешней ситуации от сложившейся в XVIII-XIX вв. заключается в том, что если в прошлом конфликт возникал между городом и деревней, то сегодня - между городом и мегаполисом. В этом новом конфликте изменились даже не участники, но знаки. В России происходит городская революция. Город наступает на мегаполис.

С.Патрушев выразил сомнение, что событие, даже такое «абсолютное», как революция, может само по себе что-то дать для осмысления политических процессов, происходящих в России. Событие должно быть понято и истолковано. Другой вопрос, что политика сегодня с трудом поддается постижению. Именно в этом, по его мнению (к которому присоединились и другие участники дискуссии), и кроется причина популярности «революционного» дискурса. В настоящее время из политики оказался вытеснен ряд значительных и социально активных группы, в т. ч. различного рода политические эксперты и консультанты, принимавшие деятельное участие в политическом процессе 1990-х годов. Вернуть себе лидерство они могут только через революционную риторику. Это в равной мере касается и левых движений, и правых националистов. Однако если первые не выходят за рамки «теоретических рассуждений», то вторые способны стать реальными глашатаями социального недовольства масс. 
ти. СПб. 2001;

Папаян Р.А. Христианские корни современного права. М., 2002; Панарин А.С. Православная чивилизачия в глобальном мupe, M., 2002;

Верин В. Концепчия права в контексте построения основ «свободной теократии" Владимира Соловьева / Российская юстичия, 2003, № 8; Ситников А.В. Православие $u$ демократия. $K$ вопросу о влиянии религиозного фактора на политическое сознание u политическую культуру России / Полития, Зима 2004-2005, № 4; Козлов Т.Л. Христианские корни континентального права / Вестник

Российской правовой академии, 2004, № 4.

2 Платон, Аристотель. Политика. Наука об управлении государством. М.; СПб., 2003. C. 395 .

3 Opmeza-u-Гассет Хосе, Восстание мacc. M., 2002.

C. 162 . стливо (выделено мною. - М.К.); в противном случае следовало бы допустить также и государство, состоящее из рабов или из животных, чего в действительности не бывает, так как ни те ни другие не составляют общества, стремящегося к благоденствию всех и строящего жизнь по своему предначертанию. Равным образом государство не возникает ради заключения союза в целях предотвращения возможности обид с чьей-либо стороны, также не ради взаимного торгового обмена и услуг; иначе этруски и карфагеняне и вообще все народы, объединенные заключенными между ними торговыми договорами, должны были бы считаться гражданами одного государства» ${ }^{2}$. А замечательный испанский философ первой трети XX века Х.Ортега-и-Гассет утверждал: «Государство, каким бы они ни было - первобытным, античным, средневековым или современным, - это всегда приглашение группой людей других людских сообществ для совместного осуществления какого-то замысла. Замысел, каковы бы ни были его частности, в конечном счете заключается в организации нового типа общественной жизни. Государство и программа жизни, программа человеческой деятельности и поведения; понятия неразделимые» ${ }^{3}$.

У разных государств возможны, конечно, разные сверхзадачи. Но все эти «программы жизни» определяются типом цивилизации, к которой принадлежит данное государство. Цивилизация, к которой принадлежит Россия, есть цивилизация европейская (или евроатлантическая) А по своему рождению и парадигме развития это цивилизация христианская. Проблема современности поэтому формулируется довольно просто: должны ли отказаться государства евроатлантической цивилизации от своей христианской основы?

Скорость, с которой зародилась христианская цивилизация - сам по себе поразительный феномен. Судите сами: минимум два тысячелетия (после Авраама) потребовалось, чтобы народ Израиля окончательно воспринял единобожие, веру в Бога Живого. И это - несмотря на все многочисленные зримые чудеса, даруемые Всевышним Своему народу (народу - а не только отдельным праведникам), несмотря на сбывавшиеся предупреждения пророков... А тут - прошло меньше трех веков после прихода на землю Спасителя, и доминирующая в европейском ареале Римская империя официально принимает христианство, которое за семь последующих веков стремительно распространяется по Европе, достигая, наконец, днепровских и волжских берегов.

Материалистическая историография утверждает, что, поскольку христианство было особенно близко «эксплуатируемым» слоям населения, постольку оно быстро распространилось среди них, а беспринципные «верхи» попросту решили приспособить новую «религию уг нетенных» для удержания и укрепления своей власти. Но достаточно 
взглянуть на исторические памятники, чтобы убедиться: христианство захватывало души людей совершенно разного социального и имущественного пөложения. Среди христианских мучеников первых веков мы видим далеко не только «простых» граждан, но и выдающихся стратегов (полководцев), и членов императорских семей, и императорских наместников, и состоятельных римских граждан в разных концах Империи - в Италии и Галлии, Элладе и Малой Азии, Армении и Сирии, Северной Африке (Карфаген, Александрия) и Британии, и т. д. и т. д.

В то же время путь евангельского просвещения не то что не усыпан розами, он залит морями мученической крови. Почему же веротерпимая Империя с такой яростью на протяжении трех веков отвергала христианское учение, замучив и казнив десятки тысяч своих вполне лояльных граждан?

Христианство - своими принцинами и христиане - своим образом жизни слишком сильно тревожили совесть, раздражали какие-то глубины языческого подсознания, чтобы можно было не обращать внимания на это мировоззрение, а тем более заимствовать что-то из него, как это обычно и происходило в империях, в которые диффузно приникали верования покоренных народов. Оставалось - либо всей душой принять христианство, либо возненавидеть. Известный популяризатор истории Церкви А.Н.Бахметева пишет об этом так: «Отчасти, может быть, сами добродетели христиан казались постоянным укором языческому обществу. Язычники терпели всякое богопочитание, пока оно не мешало жить, как жили они сами; а вера Христова изменяла во всем и

4 Бахиетева А.Н. Рассказы из истории христианской черкви. СвятоУспенский ПсковоПечерский монасmырь, 1994. Ч. I. C. 60 . образ жизни уверовавшего (выделено мною, - М.К.) $)^{4}$.

Но что имеется в виду под словами «рождение христианской ұивилизаиии»? Первый христианский император Константин Великий, еще не будучи крещен, но уже зная основы христианского учения, запретил смертную казнь, отменил кровавые игрища в цирке, велел праздновать день воскресный, принял под свое попечительство сирот и детей, брошенных родителями; облегчил участь рабов, являл милосердие к бедным и увечным, которых языческое общество оставляло без помощи и призрения... Разумеется, этим не исчерпывалось влияние христианства на публичную жизнь. Главное - появились совершенно новые принципы государственной, общественной и частной жизни, основы новых отношений между людьми. В чем их принципиальное отличие?

Для Бога (и Спасителем это впервые ясно и четко было провозглашено) не существует толпы, массы, классов, племен, наций и проч. Бог, говоря современным языком, «не выбраковывает» ни грешника, ни атеиста, ни язычника, ни иноверца. Для Него нет «отсталых», «аутсайдеров», «люмпенов», «совсем пропащих» и т. п. Наоборот, чем более человек презираем людьми, отвергаем ими, тем скорее именно он окажется избранным в глазах Господа. И если человек живет не так, как того ждет Господь, тем больше Бог о нем печется и тревожится. "Как вам кажется? - говорит Христос. - Если бы у кого было сто овеч, и одна
№ 4 (39)

Зима 2005-2006 
Суть этой, антихристианской, идеологии замечательно выразил Евгений Замятин в романе "Mы»: " вот - две чашки весов: на одной грамм, на другой тонна, на одной "я", на другой "Mы", Единое. Государство. Не ясно ли: допускать, что $y$ «я》 могуm быть какие-то "права" по отночению $\kappa$

Государству, $u$ допускать, что грамм может уравновесить тонну, - это совериенно одно и то же. Omcroda - pacnpeделение: тонне права, грамму обязанности; $u$ естественный nуть от ничтожества к величию: забьтть, что $\mathrm{mbl}$ грамм $и$ почувствовать себя миллионной долей монны...» (Замятин Е. Mьl. - В кн.: Избранное. М., 1989. C. 383).

6 Tребует вообие отдельного рассмотрения вопрос о том, почему во время гонений христиане демонстрировали массовые примеры чистой, достойной жизни. Но стоило очередному гонению утихнуть, а тем более после офичиального признания христианства, и в христианской среде оказывалось немало тех (в $\mathrm{m}$. ч. и священнослужителей), кто вел себя совериенно не по-христиански. из них заблудилась, то не оставит ли он девяносто девять в горах и не пойдет ли искать заблудивиуюся? и если случится найти ее, то, истинно говорю вам, он радуется о ней более, нежели о девяноста девяти незаблудившихся» (Мф. 18:12-14). Что это, как не свидетельство прямой противоположности христианства тоталитарной идеологин, для которой личность - ничто 5 .

Разумеется, Спаситель впрямую не обращался к владыкам земным или «к общественности», говоря, что вот так-то и так-то надо устроить государство, дабы оно могло защитить человеческое достоинство. Но, разве произнося Нагорную проповедь (заповеди блаженства); или отвечая на лукавый вопрос о том, кому платить подати; или деля трапезу вместе с отверженными - мытарями и грешниками; или особо привечая детей, Христос не говорит нам и об общественных приоритетах, 0 фундаментальных принчипах устройства жизни государства?

Христиане - не какая-то секта, погруженная в самосозерцание и строящая свою доктрину исключительно на тонкостях общения человека с Небом. Христианство предлагает достойно прожить здешнюю, временную жизнь обычному человеку, т. е. человеку во всех его социальных ролях и правовых модусах - и как собственно индивиду, и как семьянину, и как чиновнику, и как работнику, и как собственнику, и как гражданину. Чуждое и даже враждебное всякому лицемерию христианство не может и никогда не составляло одни правила для частной жизни, другие - для публичной.

Новые принципы общественных отношений, разумеется, далеко не сразу пронизали античную государственность. Дикости и варварства в Европе, да и в самой Римской метрополии с приходом в нее христианства было еще предостаточно. Причем со стороны не только язычников, но и тех, кто исповедовал себя христианином ${ }^{6}$. Да, массовая жизнь, 0заренная светом христианства, не стала образцом святости. Но именно христианство дало народам новый мощный источник энергии. Энергию обрела прежде всего сама метрополия, основной деятельностью которой, наполнившей смыслом ее существование, стало распространение христианства среди варваров.

К началу новой эры Римская империя (и Западная, и Восточная ее части) обнаруживала признаки вырождения и разложения. И хотя многие римские граждане-язычники считали, что Империя слабеет из-за «подрывной деятельности» христиан, на самом деле именно христианство помогло ей продержаться еще несколько веков, вдохнув в развращенное, ни во что не верящее и потому одряхлевшее общество и государство новый дух миссионерства и созидания. Римская империя все равно бы разрушилась, как разрушаются все империи. Но она могла умирать по-разному: оставшись языческой, являла бы в результате смердящий труп, на котором не могло бы взрасти ничего здорового; обратившись же к христианству, она стала тем евангельским пшеничным зерном, которое, «если умрет, то принесет много плода» (Ин. 12:24). 
Присутствует, заметим, не потому, что человек изначально наполнен злом, а потомy, что в природе нормального человека зло находится 6 относительном балансе с добром. В отдельньхх индивидах добро может брать верх.

Но обцество в челом, не знаючее или отвергаючее Создателя, становится жертвой накапливающегося в нем зла. И тогда баланс исчезает. зло доминирует над добром, причем зачастую выступая под видом самого добра (не случайно одно из названий сатаны пукавый). Ведь если нет внеинего источника для добрых чувств, а maким источником является Бог, дья-

волу очень легко через множество соблазнов утвердиться в людях, которые сами, не замечая того (как алкоголик почти никогда не признает свою болезнь), становятся носителями зла.

Автор сознательно следует старинной русской орфографической традичии не оглучиать приставку «без».

\section{'Бахметева А.Н.} Указ. соч. Ч. II. C. 31 .

10 Святитель Василий Великий. Избранные поучения. M., 2003.

C. $619-620$
Рим и Византия сыграли роль повивальной бабки в появлении на свет христианской цивилизации, благодаря которой Европа и стала в конечном счете определителем судеб всемирной цивилизации. Именно все большее доминирование христианских принципов, вытеснявших и замещавших языческие, в огромной степени позволило сдерживать в молодых европейских народах и их государственных образованиях то злое начало, которое всегда присутствует в человеке, не знающем истинного Бога?

Не будь христианства, Европа после неизбежного распада Римской империи являла бы собою континент, где вскоре исчезли бы остатки высокой античной культуры (пусть и языческой) с ее достижениями как в искусстве, так и в философии, юриспруденции. В конце концов из диких племен, наверное, сформировались бы государства, но представляли бы они собою лишь мрачные деспотии без тени правовой жизни (при всей жестокости европейского средневековья дикие нравы безкультурных ${ }^{8}$ подданных и их правителей, а равно законы и судебная деятельность в целом все-таки существенно смягчались христианскими принципами). Как верно заметила А.Бахметева, «общество, признающее христианский закон, не может развратиться совсем; сила чистого, нравственного закона спасает его от конечной гибели» ${ }^{9}$. Почему? Да потому, что христианская этика - это этика любви, противопоставленная этике ненависти. Как говорит св. Василий Великий, «как имеющий любовь, имеет в себе Бога, так имеющий ненависть питает в себе Диавола) ${ }^{10}$

Итак, каков бы ни был облик христианской Европы в разные периоды, какие бы трагические моменты ни сопровождали ее историю, в том числе и страшные деяния, совершавшиеся под знаком «христианства) (инквизиция, крестовые и завоевательные походы и т. п.), она, наша цивилизация шла путем мучительного, противоречивого, но во3растания в общественной и государственной жизни милосердия, справедливости, возвышения человеческого достоинства, что и составляет суть гуманизма, которым так гордится современная цивилизация.

Но, может быть, такой путь евроатлантическая цивилизация прошла бы и без христианства? Просто - как путь естественного взросления человечества. Именно так, в ключе исторического материализма и преподносится история развития человечества. Этот процесс «материализации» человеческого бытия замечательным образом иллюстрирует христианский тезис о том, что голый интеллект, разум, любующийся сам собою; ум, не одухотворенный верой в Творца, в конце концов заводит в тупик. Хорошо об этом сказал святой Феофан Затворник: «У $У_{M}$ без веры - каверзник; то и дело кует лукавые подозрения и сплетает хулы на всю область веры. Чудесам то не верит, то требует осязательнейшего чуда. Но когда оно дано бывает и обязывает к покорности вере, он не стыдится уклоняться, извращая или криво толкуя чудные действия Божии. И опытные, и умственные доказательства представляют ему в достаточном числе и силе: он и их покрывает сомнением. Разбери все его 
1 Святитель Феофан Затворник. Мысли на каждый день года. М., 2001.

C. 129 .

${ }_{12}$ Гоббс Т. Левиафан, или Материя, форма и власть государства иерковного $и$ гражданского. М., 1936.

C. 176 .

предъявления, и увидишь, что всё в них одно лукавство, хоть на его языке это слывет умностью, так что невольно приходишь к заключению, что умность и лукавство одно и то же» ${ }^{11}$.

Нет, не прошли бы мы такой цивилизационный путь без христианства. Если все-таки представить, что Европа, оставшись языческой, постепенно переняла бы эллинистическую философию и римское право (цивилизовалась в античном смысле), то сегодняшний мир был бы в корне иным. При всей высоте греческой философии, при всей детальной и тонкой разработанности римского права в них отсутствует то, что, собственно, и позволяет смягчать нравы, что делает общество гуманнее и терпимее - в них нет милосердия. Еще Т.Гоббс заметил, что в грекоримских истоках права кроются «привычки благоприятствовать (под видом лживой маски свободы) мятежам» ${ }^{12}$.

Нам скажут, что не только христианство, но и многие другие религиозно-мировоззренческие системы также отнюдь не призывают ко злу. Верно. Не случайно принцип «поступай с другими так, как хочешь, чтобы поступали с тобою» присутствует в религиозных и светских учениях совершенно разных народов мира. Но в этих учениях, религиях, философских системах добродетель зачастую оказывается лишь проявлением прагматизма. Вот, например, как мотивирует пользу гуманизма Конфуций. Один вельможа спросил его: «Как вы смотрите на убийство людей, лишенных принципов, во имя приближения к этим принципам?». Конфуций ответил: «Зачем, управляя государством, убивать людей? Если вы будете стремиться к добру, то и народ будет добрым. Мораль благородного мужа - ветер, мораль простолюдина - трава. Трава клонится по ветру».

И только христианство проповедует нечто гораздо большее, чем просто призыв не делать другому зла. Об этом говорит Сам Господь: «Вы слышали, что сказано: люби ближнего твоего и ненавидь врага твоего. А Я говорю вам: любите врагов ваиих, благословляйте проклинающих вас, благотворите ненавидящим вас и молитесь за обижающих вас и гонящих вас, да будете сынами Отиа вамего Небесно2о, ибо Он повелевает солниу Своему восходить над злыми и добрыми и посылает дождь на праведных и неправедных. Ибо если вы будете любить любячих вас, какая вам награда?» (Мф. 5:43-46). Или в другой раз в ответ на вопрос законника, спросившего, «какая наибольшая заповедь в законе?», «Иисус сказал ему: возлюби Господа Бога твоего всем сердием твоим и всею дуиею твоею и всем разумением твоим: сия есть первая и наибольшая заповедь; вторая же подобная ей: возлюби ближнего твоего, как самого себя; на сих двух заповедях утверждается весь закон и пророки) (Мф. 22:35-40; см. также Мк. 12:29-31; Лк. 10:27).

Только в христианстве высшим проявлением любви считается, «если кто положст дуиу свою за друзей своих» (Ин. 15:13). В такой любви - главный смысл христианства, что делает его самым возвышенным и самым безкорыстным мировоззрением. Причем высшее благо- 
16 Уортман Ричард С. Указ. соч. C. 33 .

${ }^{17}$ Tам же. C. 19.

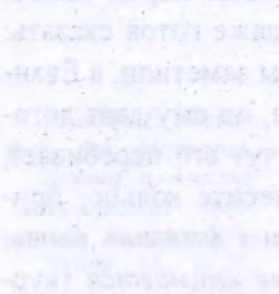

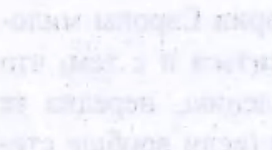

${ }^{18}$ Соловейчик $C$. "Агу" $и$ "бука". Новый мир, 1985, № 3. C. 192-193. ных троянских основателей Рима. «На такую родословную императоры Священной Римской империи претендовали со времен Карла Великого; теперь (с начала XVI века. - M.К.) они стали необходимыми атрибутами абсолютной власти» ${ }^{16}$. Языческие (античные) мотивы постепенно вливались и в оформление жизни светских владык и знати, что объяснялось не столько стремлением «проявить утонченность вкуса», сколько имело вполне определенное символическое значение. Этот процесс «возносил государей в иную сферу мироздания, где они проявляли высшие качества, дающие им право на власть. Вместе с тем эта сакральная аура отчасти переносилась и на окружение монарха» ${ }^{17}$.

Поэтому не благодаря, а вопреки христианству гуманитарное развитие шло слишком медленными темпами, а к сегодняшнему дню это развитие не только еще далеко от завершения, но, кажется, поворачивает вспять...

Любая цивилизация покоится на определенной аксиоматике, ибо при полном морально-этическом релятивизме жить невозможно. Другое дело, какие моральные аксиомы (императивы) лежат в основании той или иной цивилизации. Современный евроатлантический человек в норме не терзается выбором - украсть или не украсть, убить или не убить.

Советский педагог С.Соловейчик писал: «Люди не воруют не потому, что боятся стыда или наказания, а потому, что им противно воровать. Люди приходят на помощь друг другу не потому, что они решили каждый день делать что-то доброе или являются приверженцами теории малых дел, а потому, что любят людей. У действительно воспитанного человека нет недобрых желаний, зло претит ему. Он не сдерживается, не подавляет своих желаний, он делает все, что захочет, ни в чем себя не ограничивая, его никогда и не тянет к дурному, нечестному, некрасивому. Совесть и долг служат ему не для самообуздания, они помогают ему различать добро и зло. Можно сказать, что такой человек и не знает долга - он не принуждает себя; а можно сказать, что такой человек все делает по долгу и ничего, кроме долга, не знает - он и вправду во всем руководствуется долгом» ${ }^{18}$.

Другими словами, в целом массовое правомерное поведение основывается (пока!) не на страхе перед репрессиями, а на внутренних основах. Вот только откуда они; на чем основывается сама совесть, долг, на чем зиждется такое понимание «воспитанности»...

Этическая основа, на которой выросла и пока еще существует современная цивилизация, есть основа не «общечеловеческая», а именно христианская. Это не означает, что общечеловеческие (без кавычек) ценности противостоят христианским, враждебны им. Они не могут им противоречить, ибо из лона христианства и появились. Противопоставление в данном случае означает иное. Гуманитарные ценности, официально признанные мировым сообществом в середине XX веке, оказались помещенными в секулярную (нравственно релятивистскую) среду. Беда не в том, что эти ценности стали ценностями светского мира, а в 
том, что стремление к ложно понимаемому универсализму привело к отсечению или размыванию критериев для оценки соответствия человеческого поведения таким ценностям. Желание представить эти ценности исключительно «продуктом развития человеческой цивилизации» обернулось отрицательным отношением к ним со стороны иных культур как к ценностям, «навязываемых Западом».

На самом же деле и свобода, и достоинство человека, и гуманизм - это идеи, которым по завершении ветхозаветной истории Христос Спаситель дал новую жизнь. Человеческому достоинству не противоречит, а лишь укрепляет осознание того, что каждый является творением Божиим. Укрепляет потому, что Творец (в отличие, кстати, от языческих божков и кумиров) не считает человека своей марионеткой. Об этом сказано очень много, но приведу только одну цитату, слова, сказанные замечательным мыслителем Б.П.Вышеславцевым: «Если религиозные противники свободы попытаются выдвинуть слова «да будет воля Твоя» в защиту смиренного «послушания), как отказа от свободы, как отнятие свободы высшей Волею, то необходимо им указать, что свобода выбора и автономия личности здесь налицо и сохранена во всей неприкосновенности именно в этом «да будет». Ибо «да будет» есть самое ценное выражение свободной воли, которая может сказать и «да не будет». «Да будет» звучит из глубины автономной самости, как свободный ответ на призыв божественной Воли. «Да будет» - это я сам

Вынеславчев Б.П Вечное в русской философии. - В кн.: Эмика преображенного эроса. М. 1994. C. 200 говорю, решаясь и избирая путь, и только такой ответ нужен Богу» ${ }^{19}$.

Следовательно, где и черпать вдохновение тем, кто хочет сделать этот мир более справедливым, более милосердным, - так это в христианстве. Новый Завет и есть подлинная Декларация прав человека. Ведь в чем смысл категории прав человека? Прежде всего, в том, что они создают оболочку, защищающую человека от произвола, от покушений на достоинство личности. Эта оболочка отнюдь не разъединяет людей, как считают некоторые православные иерархи, отнюдь не ведет к атомизации общества, не формирует и не тиражирует эгоизм. Наоборот, люди скорее озлобляются, становятся недружелюбными и жестокими, ощущают себя заброшенными там, где они бесправны de jure или de facto. В Евангелиях, Деяниях и Посланиях святых Апостолов мы найдем все те принципы и постулаты, которые призваны представить человека не как мыслящее животное или человека-машину (Ж.О.Ламетри), но как создание, безгранично любимое своим Творчом и потому наделенное Им свободой воли. Любящий Отец поэтому не может желать, чтобы ктото посягал на эту свободу, в том числе на ту правовую оболочку, именуемую правами человека, которая и призвана охранить человеческое достоинство каждого. В 1924 году Иван Шмелев написал в одной своей статье: «Мы - люди, и у нас слово должно быть не волчье, а человеческое слово, Святое Слово. Из этого Слова родились чудесные основы демократизма: свобода, равенство, братство и право всякого человека раскрывать во всей полноте все возможности свои и все силы». «...И Слово было Бог» (Ин. 1:1) - вспомним мы. 
На все это могут ответить примерно так: «В конце концов, какая разница, откуда происходят гуманитарные ценности. Главное, что современное общество старается придерживаться их. Если они не чужды христианству - хорошо. Но это - его собственное, частное дело». В этом рассуждении содержится глубокое заблуждение. Оно состоит в том, что гуманитарные ценности, будучи оторваны от Неба, неизбежно начинают служить вселенскому злу и в конечном счете, дискредитируя сами себя, расчищают дорогу этому злу. И это уже - вопрос не частного отношения к Богу, а выживания цивилизации.

\section{Секуляризм - опасный вектор развития}

${ }^{20}$ Святитель Феофан Затворник. Указ, соч. С. 187.
Европейская цивилизация предпочла забыть о том, что лежит в ее основе. Подоплека понятна: если эту основу признать, придется признавать и христианское, т. е. «не научное» мировоззрение. А ныне все, что «противоречит» науке - даже не подлежит серьезному обсуждению (наподобие того, как не подлежат рассмотрению Французской академией проекты вечного двигателя). Но почему люди склонны доверять таким же людям (ученым) и не доверять Богу? И не просто не доверять, но полагать «науку» и «религию» антиномией?

Возможно, потому, что наука воспринимается через более или менее понятные, зримые или ощутимые образы. К тому же научные открытия часто становятся основой изобретений (медицинских препаратов, электрического освещения, радио и телевидения, телефона, автомобиля, холодильника, компьютера и проч.), составляющих понятия «здоровье», «безопасность», «комфорт» и т. п. Люди могут, конечно, и поругивать ученых, например, за создание смертоносного оружия. Но все равно преклоняются перед научной сферой, ибо в их глазах наука как бы подтверждает могущество рода человеческого в целом. Важно и то обстоятельство, что существует повторяемость и отчуждаемость научных или научно-технических результатов, они не зависят от склада личности (главное - соблюдение технологии). Другими словами, наука для человека есть сфера осязаемого, понятного обыденному сознанию (пусть даже ему и непонятна природа научных процессов).

Иное дело - религия. В отношениях Бога с человеком нет такой «технологической определенности», как в науке. По нашим молитвам мы можем получить просимое, а можем и не получить. Св. Феофан Затворник говорит по этому поводу: «Спроси у того, кто молился и получал просимое; он скажет тебе: «молился я о том-то и о том-то получил по прошению; теперь мне нужно то-то, молюсь и не получаю, и знаю почему: потому что никак не могу взойти в ту меру молитвы, какая была у меня прежде». Выходит, что меру эту нельзя определить с буквальною точностью. Одно только определенно верно, что дело стоит за нами, а не за Господом. Как только дойдешь до способности принять, непременно получишь» ${ }^{20}$.

Таким образом, в отличие от науки (равно как и волшебства), осязаемый дар Неба не всегда нам посылается. Для Бога важна не «словес- 
ная формула» молитвы, ибо молитва не магическое заклятие. Для Него важно наше духовное состояние. Важна и суть самой просьбы. Но даже получая просимое от Бога, иной через некоторое время может сказать в себе: «Это было удачное стечение обстоятельств, случайность»... Так что в рачиональном плане Божии чудеса «проигрывают» науке. Как сказал Господь, «сыны века сего догадливее сынов света в своем роде» (Лк. 16:8).

Секулярный человек, верящий лишь в то, что воспринимает чувственным образом; в то, что доступно его сознанию; в то, что можно рационально объяснить, опускается, как ни парадоксально, на еще более низкую ступень развития, чем дикарь. Ведь, воспринимая лишь материальный мир, мир нематериальный он не считает реальностью, заведомо исключая иномирные явления. В таком случае процесс познания становится похожим на действие всего лишь первой сигнальной

Это понятие, введенное И.П.Павловым для обозначения системь ориентировки животных на непосредственные раз-

дражители, 6 качестве которьх могуm вblcmynamb зрительные, слуховые, тактильные сигналы, связанные с приспособительными условно-рефлекторными реак-

чиями. Вторая сигнальная система означает, по Павлову, систему ориентировки человека на словесные сигналы, на основе которьх возмож-

но образование временных нервных связей.

${ }^{22}$ См.: ЛевиСтрос K. Неnрupy-

ченная мысль. В кн.: Первобытное мьишление. $M$., 1994. C.121-122.

${ }^{23}$ Lит. по: ЛевиСтрос К. Указ. соч. C. 122 . системы $^{21}$. Материалистический метод познания ограничивает себя теоретическими или практическими поисками возможностей преобразования материи, не допуская и мысли о нематериальных (иномирных) причинах того или иного явления.

Известный антрополог К.Леви-Строс убедительно показал, что «магическое» и «научное» мышление мало отличаются друг от друга. Разве что степенью детерминизма (в магии первобытных обществ он всеобщий и полный, в науке - относительный и многоуровневый $)^{22}$. В то же время события в магии детерминируются и «ненаучными факторами». Леви-Строс приводит следующую цитату (Evans-Pritchard); «Поднимет ли человека на рога буйвол, сломается ли чердак, опоры которого подточены термитами, и упадет человеку на голову, или он подхватит цереброспинальный менингит, азанде (название племени - M.K.) станут утверждать, что буйвол, чердак или болезнь - это причины, соединяющиеся с колдовством, чтобы убить человека. За буйвола, чердак, болезнь колдовство не в ответе, поскольку они существуют сами по себе; но ему присуще быть тем особенным обстоятельством, которое ставит их в деструктивную связь с определенным индивидом. Чердак бы обвалился во всех случаях, но именно из-за колдовства он упал в данный момент, когда внизу отдыхал данный человек. [...] Нет возможности выступить против буйвола и чердака, даже если их также признать в качестве причин, они не значимы в плане социальных связей» ${ }^{23}$. Следовательно, принцип причинности в рациональном мышлении объективно беднее, чем даже в магическом, не говоря уже о теологическом.

«Но кто сказал, - возразят мне, - что мистическую причинность следует включать в число реальных факторов?». Если ответить - Бог, то, конечно же, для секулярного оппонента это не будет аргументом. Поэтому скажу так: христианство накопило множество фактов и явлений, в т. ч. и сегодняшних, которые невозможно объяснить материалистически. В таком случае: разве это научно - просто отвергать их? Но ведь отвергают! Причем отвергают, основываясь на аксиоме: «Бога нет». 
Почему этот секулярный постулат стал современной аксиомой? Почему человечество приняло его?

Возможно, одной из причин постепенного расхождения науки и веры вплоть до формирования между ними противоположности стало и негативное отношение средневековых церковных деятелей к научным открытиям и вообще к развитию науки. Однако церковный обскурантизм, сыгравший трагическую роль в истории, на самом деле не имеет никакого догматического обоснования. Ощущение Бога, чувствование Его постоянного присутствия отнюдь не является помехой научному творчеству (равно как творчеству художественному или социальному). Научный и технический прогресс для христианства вовсе не есть провозвестник царства тьмы (в свое время кто-то и паровоз считал «огнедышащим драконом» - порождением дьявола).

Напротив, Господь не случайно даровал Своему творению - человеку - огромные возможности для познания и применения новых знаний в целях облегчения, точнее, облагораживания жизни на Земле. И вообще религиозное чувство отнюдь не означает знак равенства с регрессом. Многим великим ученым (например, Ньютону, Пастеру, Ломоносову, Павлову) в научной деятельности, по их собственному признанию, отнюдь не мешала, а, скорее, помогала искренняя вера в Создателя и любовь к Нему. Стремление к познанию мира приветствуется в Священном Писании. Царь Соломон, например, воспевая премудрость, т. е. ум, одухотворенный Богом, говорит:

«Сам Он даровал мне неложное познание суцествующего, чтобы познать устройство мира и действие стихий,

начало, конеч и средину времен, смены поворотов и перемены времен,

круги годов и положение звезд,

природу животных и свойства зверей, стремления ветров и мысли людей, различия растений и силы корней» (Прем. 7:17-20).

Святые отцы Церкви никогда не противопоставляли рациональное знание мистическому, науку - вере. Наоборот, они утверждали их гар-

24 См., например: Святитель Василий Великий. Указ, соч. С. 172 , $176-177$. моническую взаимосвязь ${ }^{24}$.

Гносеологический принцип в «науке» и «религии» (кавычки здесь лишь оттого, что эти понятия разъединены самими людьми) - один и тот же. Разница - в онтологической презумпции процесса познания: «Бог Создатель всего сущего» или «все сущее - результат природной стихийности». Я не говорю здесь о причинах появления второй презумпции. Говорю лишь о том, что нет преграды между верой в Бога и познанием разных сфер Его творения.

Итак, включение фактора Неба в частную и публичную жизнь показатель не «отсталости», а, напротив, более высокой ступени развития соответственно личности и общества. И наоборот. Общество, считающее прогресс и цивилизованность не совместимыми с религиозным сознанием, стремясь «очистить от религиозного смысла» аксиомы, являющиеся именно христианскими аксиомами, в итоге дичает. Не мною 
сказано, но так оно и есть: оболочка цивилизованности современного евроатлантического человека (а цивилизованность эта имеет, как уже сказано, христианскую основу) весьма тонка. Она, эта оболочка, - как гумус (плодородный слой Земли), который ныне также все более истончается. Но, несмотря на это, как по-прежнему мы нещадно эксплуатируем почву, так и оболочку собственной цивилизованности не бережем. В итоге - как решение проблемы продовольствия на планете уже видится в трансгенных или по-иному искусственно созданных продуктах, так и с презрением относясь к христианским принципам, мы объективно ниспровергаем нынешнюю цивилизацию.

Сегодняшний мир (во всяком случае, правители мира сего) не осознает, что материалистическое мировоззрение не содержит в себе этических принципов. А раз так, рушится и то, что современное общество считает заслугой «прогресса» - личная и гражданская свобода, гуманизм, права человека, правовое государство и т.д.

Интересно, что часть либеральных идеологов также не согласно с упованием на материализм, в чем, впрочем, нет ничего странного, ибо либерализм отнюдь не тождествен и даже противостоит вульгарному экономическому детерминизму (однако именно это сектантское на-

${ }^{25}$ Вирочем, по словам самого Фукуямbl, авторство идеи принадлежит русскому эмигранту Александру Кожеву.

${ }^{26}$ Цит. по интернет-версии (http:// patriotica.rulactual/ fukuyama_end.html). правление ныне оккупировало понятие «либерализм»). Френсис Фукуяма, известный авторством ${ }^{25}$ нашумевшей в конце 80 -х годов XX века концепции «конца истории», т. е. завершения идеологической эволюции торжеством либеральной идеи, справедливо заметил, что «современный мир обнажает всю нищету материалистических теорий экономического развития» ${ }^{26}$, а безрелигиозность порождает «духовную пустоту либеральных потребительских обществ». И это, по его признанию, есть «идеологический дефект либерализма». Однако верная констатация приводит автора к ничем не обоснованному убеждению, что данный «дефект» не катастрофичен.

В том-то и дело, что катастрофичен. Потеря видения причинноследственной связи между отвержением евроатлантической цивилизацией собственной христианской основы и наступлением страшных последствий (социальных, техногенных, природных катастроф) ведет к тому, что наша цивилизация переживает длящийся процесс самоубийства.

Самоубийство происходит по причине того, что наша цивилизация уже минимум как лет триста покидает свое лоно, в котором родилась и развивалась, - христианство. И не просто покидает, но и, как нувориш, стыдящийся и потому отрекающийся от своих корней, старается опорочить, принизить христианство, поставить его в один ряд с категориями, означающими регресс, отсталость, враждебность всему новому. Отвечая на такие представления о христианстве, член Конституционного суда Армении Р.А.Папаян пишет: «Смеем возразить: в том-то и вся беда современной эпохи, что мир изрядно подзабыл, что Бог и божественные истины пребывают вне времени, и возомнил, что автономные от богоданных истин интеллектуальные поиски человечества являются 
Папаян P.A. Указ. соч. С.19.

${ }^{28}$ Такая вера на самом деле тоже далека от рачиональности, ибо, например, вероятность образования всей человеческой хромосомы, содержащцей весь набор генов, колеблется меж жу $10^{12000000} u$ $10^{24000000}$ (Barrow

J.D., Tipler F.J. Anthropic cosmological principle. Clarendon press, Oxford University press, New York, 1986). "По-видuмаму, - пииет физик О.В.Петренко, - случайное появление человека не более реально, чем, например, возможность набора всемирной энииклопе-

дии $c$ помочьью взрыва в типографuu» (http:// www.zavet.ru/somnfizik.htm) прогрессом. Разительный парадокс заключается в том, что почему-то основанность своих правовых норм на религиозно-нравственных ценностях христианства он считает ходом назад, а почти полное базирование сегодняшних правовых представлений на языческом в своей основе римском праве считает весьма прогрессизным» ${ }^{27}$.

Отказу от «фактора Неба» особенно способствует процесс глобализации, в рамках которого (здесь я не даю оценку, а просто констатирую) закономерно приравнивание христианской религии к множеству верований (в том числе к старым и новым языческим культам и даже к атеизму, который также является верованием в то, что вселенной управляет случайность ${ }^{28}$ ). Глобализация приводит к смешению вопроса о свободе совести с вопросом об основах государственности и доминирующей в данном обществе этики. Под видом приверженности свободе совести любое упоминание о религиозном характере того или иного публичного явления, процесса, а тем более об их метафизической основе, считается предосудительным, поскольку якобы это нарушает принцип равноправия. Из последних событий вспомним хотя бы о том, какую бурную дискуссию вызвал вопрос, упоминать ли о христианских корнях европейской цивилизации в проекте Конституции Европейского Союза. Одной из причин такого спора стало стремление «не обидеть) весьма многочисленную ныне мусульманскую диаспору, проживающую во многих европейских странах. К сожалению (и, на наш взгляд, это будет иметь дальние негативные последствия), победила секулярная позиция - Конституция ЕС лишена упоминания о христианских корнях Европы.

Понятно, почему глобализация способствует равнодушной нивелировке религий: технократически воспринимаемые экономические и политические интересы требуют своей реализации с помощью категорий «толерантности и плюрализма». Вновь подчеркнем: эти категории отнюдь не противоречат сути христианства, более того, на самом деле рождены именно им. Но поскольку технократы воспринимают названные категории отнюдь не в качестве подлинных ченностей, а только как инструменты для достижения своих целей, постольку они не видят необходимости наполнять их моральным содержанием, не задумываются над тем, где в них пролегает грань между добродетелью и пороком (а такая грань пролегает в любом земном понятии и явлении, даже самом благородном и возвышенном), и, следовательно, расширяют эти категории до пределов государственной и международной защиты самого зла или, во всяком случае, порока.

Глобалистский мир в его технократической версии есть пародия на христианство (а всякое передразнивание Бога - от дьявола). Смотрите: для этого мира ведь тоже «нет уже Иудея, ни язычника; нет раба, ни свободного; нет мужеского пола, ни женского...» (Гал. 3:28). Но Апостол не этим заканчивает фразу, а словами: «ибо все вы одно во Христе Иисусе». Именно в этом принципиальное отличие от секулярного «равенства». «Во Христе Иисусе» - это, прежде всего, не формальная хри- 
стианская идентификация, а умение различать, в чем именно состоит грех. Причем евангельское понятие греха не только ни в чем не противоречит современным общепризнанным правовым дозволениям, обязанностям и запретам, но является их источником. В современном же мире расовая, этническая, религиозная толерантность, политкорректность, унисекс и проч. - все это воспринимается безотносительно понятий добра и зла, добродетели и порока. Не случайно толерантность скорее выглядит как показатель внешней «добропорядочности», но не усвоена глубинным сознанием. Людям говорят, что терпимость - признак цивилизованности, а потому те, кто хочет выглядеть цивилизованным, должен соответственно не представать в глазах общества расистом, ксенофобом, сексистом и т.д. Однако, как говорится, «поскребите» такого и обнаружите расиста, ксенофоба и сексиста. Все потому, что глобализм не несет в себе великую идею всемирного братства, о котором и говорил Апостол: «ибо все вы одно во Христе Иисусе. Если же вы Христовы, то вы семя Авраамово и по обетованию наследники» (Гал. 3:28-29). Для христианина, в отличие от секулярного человека, не существует слова «казаться", для него есть только слово «быть».

Bсе большее доминирование материалистического мировоззрения неизбежно возносит экономический детерминизм на высшую ступень. И тогда, ничем не сдерживаемый он доходит до утилитаризма («всё, что не приносит видимую пользу, должно быть отброшено») даже в тех сферах, которые ранее казались выключенными из понятия «экономика» или «народное хозяйство». Складывается ощущение, что появился главный современный идол, имя которому эффективность. Именно в угоду ему государства подчиняют едва ли не всю свою деятельность, и даже свои стратегические цели (как тут не вспомнить, что уже не первый год Президент РФ, как заклинание, произносит слово «эффективносты» и провозглашает в качестве цели «конкурентоспособность России». Даже если он вкладывает в это понятие не только рыночный смысл, в любом случае такая цель заведомо принижает дух, подчиняет развитие страны «долу», а не «горе»).

Глобалисты, в родовом смысле оставаясь в общем-то капиталистами, как ни парадоксально, восприняли идею антикапиталиста К.Маркса (хотя тут нет парадокса, если вспомнить, что материалистическое мировоззрение является основой и там, и тут). Так вот, ранний Маркс («К еврейскому вопросу»), полемизируя с Б.Бауэром, утверждал: «Человек политически эмансипируется от религии тем, что изгоняет ее из сферы публичного права и переносит ее в сферу частного права (курсив мой. - М.К.). Она уже не является духом государства, где человек хотя и в ограниченной степени, в особой форме и в особой сфере ведет себя как родовое существо, в сообществе с другими людьми; она стала духом гражданского обшества, сферы эгоизма, где царит bellum omnium contra omnes (война всех против всех. - М.К.). Ее сущность выражает уже не общность, а различие. Религия стала выражением отделения человека от той общности, к которой он принадлежит, от себя само- 
${ }^{29}$ Маркс К. $u$ Энгельс Ф. Собр. соч. T. 1. С. 390.

30 Московские новости, 2004, № 30 .

C. 8 .

"1. Tакое решение по жалобе прихожсанки Т.Малахович принял, например, Южно-Сахалинский городской суд (см.: Российская юстичия, 2002, № 5. С. 51). Правда, впоследствии данное решение было отменено вышестоящей судебной инстанцией, но факт от этого не становится менее примечательным.

32. Эта прихожанка, М.Гинн, будучи незамужней, вступила в сексуальную связь с разведен- го и других людей, - чем и была первоначально. Она является всего только абстрактным исповеданием особой превратности, частной прихоти, произвола) ${ }^{29}$.

Подлинный прогресс, под которым понимается не совершенствование машинной цивилизации, а прогресс моральный, возможен лишь с именем Христа. Но Его имя ныне тщательно стирается. Пока не запретами, а сознательным принижением, «приземлением», обмирщением христианства. Веру и христианские обряды уже представляют в глазах людей как разновидность шоу или, во всяком случае, как нечто такое, что стоит в одном смысловом ряду с астрологией, эксцентричностью, чудачеством, видом разрядки и снятия стрессов и т. д. и т. п. Если сегодня кто-то из политических деятелей вознамерится открыто проводить причинно-следственные цепочки публичной жизни с промыслом Божиим, его сочтут политиком несолидным, отсталым или немного сумасшедшим. Апелляция к Небу ныне считается чем-то неприличным в «приличном обществе», а обращение к религии - предосудительным. Маленькая иллюстрация: известный немецкий кинорежиссер Фолькер Шлендорф (создатель одного из знаменитых антитоталитарных фильмов «Жестяной барабан») сказал в одном интервью, что «мир все так же полон несправедливости. Некоторые не перестают твердить: «Рынок все отрегулирует», но любой интеллигентный человек знает, что это не так». И вдруг, будто боясь (или действительно боясь), что его заподозрят в религиозности, оговаривается: «Отсюда вовсе не следует, что надо искать спасение в религии $[\ldots]\rangle^{30}$.

Как бы улавливая общую атмосферу, различные государственные институты стремятся показать себя ревнителями «религиозного равноправия». И вот уже в России появляются судебные решения (например, в 2001 г.), по которым от имени государства признается незаконным (?!) решение об отлучении от Церкви, по аналогии с незаконностью исключения из общественного объединения ${ }^{31}$. На это могут возразить, что дело обстоит как раз наоборот: в России государство берет под опеку православную Церковь, создает ей преференции, при ее благожелательном к этому отношении (чего стоит, например, заявление Генерального прокурора РФ о молельных комнатах в прокуратуре). Но это лишь другая сторона того же прочесса обмириения христианства, приравнивания его к утилитарным политическим средствам. И уж точно здесь даже не пахнет попыткой органического вплетания христианских принципов в публичную жизнь. Это - неуклюжая попытка вновь воспроизвести идею «симфонии властей».

О схожих процессах секуляризации в США под знаком «равноправия и соблюдения гражданских прав» свидетельствует, например, Чарльз Колсон, бывший советник американского Президента Р.Никсона. В частности, он описал случай, как суд (1984 г.) обязал Коллинсвиллскую «Церковь Христа» выплатить своей прихожанке 390000 долларов в качестве «компенсации за моральный ущерб», нанесенный путем публичного объявления приходу о ее грехе ${ }^{32}$. Комментируя это решение, 
ным мужчиной. (см.: Колсон Ч. Конфликт чарств. Пер. с англ. М., 1996. C. 230-232).

${ }^{33}$ Там же. С. 232.

${ }^{34}$ Tay sce. C. 236.

15 Если же 20ворить об обрядовости, то она не является непременным атрибутом любой религии.

В то же время

в определенном смысле и у материалистов есть обряды. Даже если не принимать во внимание явную обрядовость в тоталитарных государствах, разве не представляют собою обряды в демократических государствах дипломатический протокол, некоторые судебные прочедуры, черемонии регистрачии брака, гражданской панихиды $u$ проч.?
Колсон пишет: «Христиане справедливо усматривают в вынесенном судебном решении посягательство государства на прерогативы Церкви (пусть даже в данном случае речь идет о сектантской церкви. - M.К.) $\}^{33}$. Колсон приводит и другие случаи секулярного нападок на религию и религиозные организации (прежде всего, христианского толка). Но стоит обратить внимание на выдержку из особого мнения двух судей по так называемому «Абингтонскому делу» (1963 г.). Решением суда тогда были запрещены публичное чтение Библии и проведение общей молитвы в школах. Мотивировалось это решение тем, что, хотя религия имела решающее значение для человечества, но государство должно занимать нейтрально-безразличную позицию ко всем религиям в любой их форме. Так вот, двое судей, не поддержавших такое решение, заявили, что «односторонняя приверженность идее нейтралитета способна привести... уже не просто к невмешательству в религиозные дела, чего требует Конституция, но к бездумно-исступленной преданности всему светскому и пассивной, а то и активной, враждебности к религиозному (выделено мною. - М.К.) $)^{34}$.

А вот и недавний случай (2003 г): в США разгорелся судебный скандал из-за каменного изваяния страниц Библии с перечислением десяти заповедей. Этот памятник установлен в здании Верховного суда штата Алабама, и оттуда его требует убрать федеральный апелляционный суд. Он постановил, что такое изваяние не может находиться в госучреждении. И только судебный прецедент помог сохранить изваяния. Дело в том, что тот же апелляционный суд разрешил сохранить «заповеди» в виде бумажных листов на стенах судов в Пенсильвании и Джорджии, поскольку местным юристам удалось доказать, что это не просто страницы из Библии, а исторические документы.

...Когда у дьявола не получилось с его «проектами» коммунизма и фашизма (хотя он и преуспел здесь по части пролития морей крови), он избрал новый - секуляризм. Если подсознательно евроатлантическая цивилизация отворачивается от христианства в силу гордыни, которая, в свою очередь, напрочь отвергает смирение и желание постичь волю Небес, то сознательно этот процесс аргументируется необходимостью обеспечения свободы и равноправия.

Из предыдущего изложения нетрудно понять, что речь идет об особой чивилизачионной роли христианства. Значит ли это, что речь идет о нарушении принципа равноправия? Нет!

Христианству постепенно и к XX веку полностью отведена роль исключительно религиозного учения (причем одного из многих), частного дела. В таком случае действительно, согласно современной правовой концепции, христианство заслуживает ровно такого же государственного отношения, как и все иные религии или верования (даже самые экзотические). Но разве материализм - это не религия? Ведь и он основывается на неких догматах: «мир - продукт случайного набора элементов», «человек - продукт эволюции», «материя - первична, сознание - вторично $)^{35}$. И разве материалисты не веруют, например, в 
собственные догматы (аксиомы), строят жизнь, исходя из них, из материалистической причинно-следственной связи?

В таком случае, чем христианская религия «ущербнее» материалистической? Мне ответят: «Тем, что наука может что-то рационально доказать, а религия - нет». Не стану повторять сказанное выше о научном и религиозном сознании, тем более, что об этом уже много было сказано умными людьми. Добавлю лишь одно соображение. Если «материя - это объективная реальность, данная нам в ощущениях》, то почему за основу берутся лишь оиущения одних людей и игнорируются ощущения других? Для очень многих верующих христиан ощущение Бога, ощущение Его чудес есть не только духовное, но нередко и физическое ощущение, т. е. факт. Почему тогда эти факты и документальные записи о них просто не принимаются во внимание? И вообще - где проходит граница между «объективным» и «субъективным»? Есть ли она вообще? Понятно, что пересмотр, отказ от привычного миропонимания представляет собою весьма болезненный процесс. Но ведь речь идет о судьбе цивилизации...

Посмотрим теперь на проблему с другой стороны. Не только материализм, но и христианство - это философия, мировоззрение. Почему же государства восприняли в качестве базовой одну философию и отвергли другую? Может быть, христианское мировоззрение противостоит развитию, прогрессу? Ничуть (об этом уже говорилось выше). Может быть, христианство требует подавления социальных инстинктов, например, инстинкта собственности? И этого нет. Св. Иоанн Златоуст, например, разбирая Послание Римлянам, замечает как вполне естественное, что «издревле с общего согласия всеми принято, чтобы правители содержались на наш счет, потому что они, оставив собственные дела, пекутся о делах общественных и все свое время проводят в заботах

36 Святитель Иоанн Златоуст. Толкование на Послание Апостола Павла к Римлянам (глава XIII). В кн.: Власть... C. 9 . о том, чтобы наиа собственность была неприкосновенна» ${ }^{36}$. Может быть, философия христианской жизни требует распространения монастырского устава на гражданскую жизнь и превращения последней в сплошную аскезу? Нет, никогда христианство так вопрос не ставило. Один из принципов христианства состоит в соразмерности собственных сил подвигам. То есть Господь, зная каждого из нас, никогда не ставит человека в такие жизненные обстоятельства, которые потребуют от него большего нежели он способен совершить - духовно и физически.

И тем не менее трагический для человечества переход от христианского мировоззрения к материалистическому совершился. В таком случае принцип равноправия в самом его фундаментальном смысле оказался нарушенным как раз после того, как материалистическое мировоззрение оттеснило мировоззрение христианское в сугубо религиозную сферу.

«Хорошо, - скажут мне, - Европа действительно полторы тысячи лет жила на христианском фундаменте. Но он был размыт - сначала расколами, ересями, а затем проникновением в массовую жизнь материалистической философии. И теперь эта основа - секулярная. Это - 
тоже результат естественного течения жизни. А вы, христиане, требуете вернуть современную цивилизацию к тому, что она уже отвергла»...

Во-первых, действительно, цивилизационную парадигму никому из людей искусственно никогда не удастся переломить, изменить. Возможно, и нынешнее развитие процессов будет продолжаться. Но ведь пока не поздно совершить и такой же свободный выбор вновь в пользу христианского мировоззрения, ибо на кону коллапс цивилизации. Если осознание альтернативы овладеет множеством умов и душ, то и преображение цивилизации, государственности на христианских принципах будет столь же естественным.

Во-вторых, равноправие в материалистической системе координат отличается от равноправия в христианском понимании. Приведу слова Святителя Николая Сербского (Велимировича):

«Бог есть любовь, но Бог не есть равенство. Равенство изгнало бы и справедливость, и любовь, изгнало бы нравственность.

Любит ли муж жену за равенство?

И мать любит ли своего ребенка за равенство?

Разве друзья любят друг друга за равенство?

Неравенство - основа справедливости и побудитель любви.

Пока живет любовь, никто не вспоминает о равенстве.

Пока царит справедливость, никто не думает о равенстве.

Когда уходит любовь, люди говорят о справедливости и подразумевают равенство.

Когда за любовью уходит и справедливость, начинают говорить о равенстве и подразумевают безнравственность, то есть изгнанную нравственность подменяют порочностью.

На могиле любви вырастает справедливость, на могиле справедли-

37 Цum. no: Год дуии. . Православный календарь с чтением на каждый день. 2004. Единеи, 2003. C. 317 .

is Святитель Василий Великий. Указ. соч. С. 619. вости растет равенство» ${ }^{37}$.

Удивительным образом эти слова созвучны сказанным более полутора тысяч лет назад св. Василием Великим, который говорил о необходимости не просто любви, а любви, равно распространяемой на всех: «Как Бог всем дает возможность равно приобщаться света, так и подражатели Божии да изливают на всех общий и равночестный луч любви) ${ }^{38}$.

Другими словами, если на первое место общество ставит равенство, а не милосердие, тогда не получается ни равенства (равноправия), ни общественной нравственности.

Таким же образом необходимо подходить и к роли христианской философии. Восприятие ее в качестве официальной основы и государственности, и международных отношений будет означать формальное неравенство по отношению к иным мировоззренческим системам (хотя, как уже говорилось, материализм в качестве основы формально также противоречит принципу равенства, ибо это - лишь одно из мировоззрений). Но в таком случае люди должны ответить на принципиальный для всего последующего развития вопрос: готовы॰ли они оставить христианство лишь как религию частного человека или, вопреки формальному соответствию всем международно-правовым документам, 
принять христианское мировоззрение в качестве главной основы своего гражданского бытия? Принять потому, что только оно облагораживает всю нашу жизнь, ибо только в нем любовь (доброта, милосердие, терпение, самопожертвование) является центральным пунктом и, следовательно, удовлетворяет наши потребности в справедливости и равенстве тем, что попросту не возбуждает ощущения их нехватки.

B-третьих. Любая власть основывается на том, что презюмирует некую массовую норму, имеет обобщенный образ правомерного поведения. Мы не замечаем, что живем, руководствуясь вполне определенной этикой; мы с детства понимаем, не зная даже еще о юридических запретах, что именно санкционировано обществом, а что подвергнуто осуждению. Другими словами, есть определенная мораль, на которую опирается вся жизнь - как частная, так и публичная (лишний раз напомним, что господствующая пока евроатлантическая мораль является моралью христианской, во всяком случае, основана на ней).

И вот, если эта мораль разрушится, на что будет опираться закон? Тут не помогут никакие правовые запреты, многие из которых, впрочем, и сами уже подвергаются ревизии (то, что вчера было правонарушением, сегодня, смотришь, уже считается правомерным поведением, разве что не подвигом). Тогда институты государственности и гражданского общества в нынешнем виде неизбежно падут. Разумеется, что-то воздвигнется и на их месте. Но это «что-то» неизбежно будет настолько мерзким, что многие будут желать избавления от земной жизни. Понимая, что сейчас скажу страшные, возможно, кощунственные вещи, тем не менее решусь на это ради того, чтобы ярче представить одно из возможных следствий крушения внутренних нравственных ограничителей. Итак, представим на минуту, что у нормального человека перестает действовать отвращение к убийству, тем более к убийству ребенка или иного беззащитного. Государство столкнулось бы с ситуацией, когда, не находя сил справиться с числом убийств, сопоставимых с сегодняшним числом нарушений дорожного движения, ему пришлось бы законодательно уже не запрещать, а «регулировать» убийства - «не замечая) некоторые их «виды» или выдавая самые настоящие лицензии и квоты на убийства (это даже не моя фантазия; современный фольклор мегаполисов уже выражает то, что сидит в головах у многих людей).

Вновь слышу возражение: «Вот, начитался и насмотрелся человек футуристических антиутопий и пугает тем, чего не может быть никогда. Каких только мрачных и жестоких времен не бывало в истории, и всегда человечество справлялось. Справится и с нынешними негативными проявлениями, сопровождающими прогресс».

Тогда спрошу и я: на основе чего справится? Наука вновь придет на помощь? Или здравый смысл возобладает?

Наука? Допустим. Но рассуждая в рационалистических терминах, давайте честно спросим себя: если общество в упадке и падение ускоряется, какие научные открытия и технические изобретения помогут его спасти? Появятся, например, новые источники физической энергии. Но 
39 Bnору ужсе говоpumb o "сверхправах человека». Об этом задумываются уже отнюдь не противники демократии и прав человека. Вот что, например, говорится в статье, опубликованной журналом "Посев»: "B xоде mpuумфального ше ствия безграничньхх прав и свобод в США выработался кодекс, получивиий название "Political correctness", codepжсаиий суровую регламентачию поведения $u$ мынления, сочетаюиую аномальную свободу с неестественными запретами: в Нью-Йорке, к примеру, издан закон (со следами победивмего феминизма),

разрешаючий женцинам нахоdumbcr 6 метро 6 обнаженном до пояса виде, но при этом запрешаючиий под страхом строгих репрессий поднимать глаза на подобную пассажсику. Ни при каком брежсневизме нам не снился такой тоталитарный заповедник, известный только из антиутопий» (Тальчева Р. Россия перед личом новой тотальной идеологии. - Посев, 2000. № 1. C. 37). ведь и сама энергия нужна для чего-то. И если это «что-то» просто иной уровень потребления, в свою очередь, основанного на желании поразить окружающих каким-либо необычным приобретением, возвыситься «над толпой» или, наоборот, «быть не хуже других» в соответствии с навязанными стандартами потребления; если физическая энергия нужна для новых, все более утонченных видов удовольствий, в т. ч. порочных - что изменится от этого в мире, в отношениях между людьми? Скорее, напротив, деградирующее общество будет воздействовать (впрочем, уже воздействует) на выбор все более противоестественных научных направлений и технических изобретений вроде клонирования человеческих особей и искусственных бриллиантов, сделанных из праха усопших родственников.

Здравый смысл? Что ж, неплохая основа. Но есть ли уверенность, что ныне принципиально не изменилось наполнение понятия «здравый)? Ведь в мире в качестве нормы, стандарта укореняются явления, которые еще вчера считались воплощением отвратительного порока. Сегодня же их берут, правда пока с оговорками, под официальную защиту. Вот один лишь пример. По сообщению агентства «Reuters», врачи одной из норвежских тюрем выписывали препарат «виагра» заключенным, отбывающим наказание за преступления сексуального характера. Эти действия сотрудник колонии, что неподалеку от Осло, мотивировал тем, что «заключенные - это нормальные люди, которые время от времени хотят иметь полноценные половые контакты, и, если у них возникают проблемы, они, как и все остальные люди, имеют полное право получить помощь». Возможно, информация о действиях тюремных медиков не дошла бы до руководства колонии, если бы один из заключенных, отбывающий наказание за инцест, не стал грубо домогаться своего 16-летнего сына во время тюремного свидания...

Этот пример - один из множества ему подобных, демонстрирующих, что происходит, когда категории гуманизма, прав человека, достоинства личности и т. д. отрываются от своей естественной - Небесной первоосновы, когда игнорируется постулат, что Сам Бог является источником естественного права. А происходит, говоря языком физики, перемена полюсов. Ведь в е́стественном праве абсолютны не сами правовые категории. Абсолютен лишь их критерий - соответствие божественным императивам, непосредственно полученным людьми вначале от Бога Отца и затем развитым Богом Сыном. А сегодня, наоборот, моральный критерий стал релятивистским, а правовые категории, прежде всего, категория прав человека ${ }^{39}$ - абсолютизированы. Не удивительно, что многие инстинктивно отвергают такую абсолютизацию. Но вместе с нею (где-то более явно, где-то подспудно) отвергаются и сами благородные идеи (того же естественного права), которые были предназначены Богом для возвышения и одухотворения человеческого бытия. В сознании людей постепенно девальвируются сами правовые ценности, но нет пока признаков их переосмысления на основе обращения к подлинному критерию их цивилизованной применимости. 
Вот почему можно констатировать, что происходит уже даже не зарождение, а становление постхристианской цивилизации. Не в том, однако, смысле, что вот, мол, минула христианская цивилизация, которая сыграла-де свою роль и уступила место «более прогрессивной мировоззренческой основе». Нет, я говорю о постхристианской цивилизации лишь в субъективном смысле, т. е. как о сознательном отказе от базовых ценностей, что, безусловно, есть регресс. Однако наша цивилизация пока еще держится на остатках христианской нравственности и потому объективно еще является христианской. Но она переживает кризис, который, как всякий кризис, может стать либо отправной точкой для перехода преображения христианской цивилизации, 'либо... для катастрофы. Как верно подметил архимандрит Софроний (Сахаров): «Нашу эпоху некоторые склоняются характеризовать как похристианскую. Я же лично, в пределах моих познаний истории мира и христианства, убеждаюсь, что христианство, в его подлинных измерениях, еще никогда не было воспринято широкими массами как должно (выделено мною. - М.К.). Государства претендовали на именование «христианские», и народы их носили маску благочестия, силь же его отреклись (2 Тим. 3,5$)$ : жили и живут по-язычески. Как ни странно, но именно христианские государства веками держат большую часть вселенной в железных тисках рабства; в последние же годы окутали мир мрачной тучей апокалиптического огня. В современном кризисе христианства среди народных масс вполне оправданно усмотреть бунт естественной

40 Цum. по: Год души... C. 299. совести против тех извращений, которым подверглось Евангельское учение в его исторических судьбах ${ }^{40}$.

Где выход?

На мой взгляд, бесполезно и даже вредно искать выход, основываясь на предположении, что при определенных усилиях большинство людей со временем станут добрыми христианами. Такое предположение является утопическим. Об этом свидетельствуют как само Священное Писание, так и история человечества. Еще несколько тысяч лет назад Псалмопевец восклицал: "Сказал безумеч в сердие своем: “нет Бога"» (Пс. 13:1). Следовательно, даже в традиционном религиозном обществе были, говоря современным языком, атеисты или те, кто, формально поклоняясь Богу, не хотел даже на йоту отнять что-то у своих плотских потребностей. «Званы», конечно, все, а вот «избранных» во все века было мало. И до последних дней, по пророческим словам Иоанна Богослова, останутся множество людей, которые, покорившись зову плоти, открыто перейдут на сторону князя тьмы: «И поклонятся ему все живущие на земле, которых имена не написаны в книге жизни у Агниа, закланного от создания мира» (Откр. 13:8)...

Сколько раз уже бывало: как только презумпция «массовой святости» становилась официальной и на ней выстраивалась какая-либо система, за нею сразу же показывалась дьявольская ухмылка. Любой христианин знает, что до Второго пришествия Христа дьявол имеет возмож- 
"Сантуччи Луиджи. "Не хотите ли и вы отойти?». Размышления о земном пути Иисуса Христа. Пер. с итал. М., 1994. C. 84 .

${ }^{42}$ Шмеман Александр, протопресвитер. 3 ж жизнь мира. Свято-Духов монастырь, 1991 C. $42-43$. ность и активно пользуется ею для искажения наших помыслов, мыслей и дел. И когда в желаниях, стремлениях переустроить этот мир присутствуют не очень безкорыстные мотивы, или для бпагих целей используются не благие средства, или если сами замыслы не одобряет Господь, тогда показывается князь тьмы. Ведь, не имея дара самому что-либо творить, он свои силы направляет на передразнивание добра. Как метко заметил религиозный писатель Луиджи Сантуччи, «сатана мучается завистью к Христу и подражает Ему, как только может. И потому наряду с воплощением Бога появляется и воплощение сатаны ${ }^{41}$.

В то же время и упование на исключительно рациональные, светские методы «ремонта» основания современной цивилизации не только не даст результата, но и ускорит катастрофу.

Фактически оба эти направления предполагают, что либо Церковь использует силу государства для «духовного окормления», либо государство начинает спекулировать на религиозных чувствах граждан, привлекая для своих целей Церковь как учреждение. Слова Иисуса Христа: «отдавайте кесарево кесарю, а Божсие Богу» (Мф. 22:21; Мк. 12:17; Лк. 20:25) были ведь сказаны не только для конкретной ситуации, ибо каждое слово в Евангелии имеет священный и непреходящий смысл. Мы же об этом часто забываем. Но тогда что же остается? На наш взгляд, остается встречное движение светских властей и христианской Церкви. Но это движение не есть их сближение вплоть до растворения друг в друге и неразличимости. Это движение не во имя новой теократии или «симфонии властей», а во имя облагораживания остающегося светским мира.

Для христианства и его миссии (миссии христианской Церкви) одинаково безсмысленно (в земном понимании) и опасно (в понимании мистическом) как разрывать единую ткань «души» и «тела», уходя от проблем земного общества, так и интегрироваться в общество, пытаясь институционально «одухотворять прогресс». Об этом хорошо сказал протопресвитер А.Шмеман: «Мы должны понять, что не в том главная трагедия, что христианство пошло на недолжный компромисс с «миром сим», 'а в том, что, «спиритуализировав» себя, оно превратилось в «одну из религий», обслуживающих людей и их «духовные нужды», тогда как вошло оно в «мир сей» как победное благовестие Царства Божьего, разрушения смерти и спасения, созданного Богом мира. [...] И вот, христиане, и целые «Церкви», восторженно включаются в эту «борьбу за прогресс», своими делают «научные идеологии», этот прогресс доказывающие, и призывают христиан активно участвовать в этом служении миру и человеку) ${ }^{42}$.

О каком же тогда движении идет речь? Или в чем состоит смысл облагораживания мира? Ответ на этот вопрос давно дан Спасителем в двух главнейших заповедях любви $-\kappa$ Богу и ближнему своему (Мк. 12:29-31).

Как этот смысл мог бы быть воспринят Церковью? Прежде всего путем изменения соотношения между сотериологической и миссио- 
нерской парадигмами церковной деятельности. При всей важности личного и соборного спасения христиан основной остается порученная Самим Христом миссия проповеди, распространения Евангелия по всему миру. Но миссия эта не может быть понята узко, так сказать, бюрократически. То есть речь не идет о «формальном информировании» 0 Благой Вести. Речь может идти о таком благовестии, когда обычные люди увидят в нем то главное, чего им не хватает ни в мирской, ни даже в духовной жизни; о благовестии любви - всеохватной, не знающей никаких различий между людьми, единственно уравнивающей всех.

Сегодня заповеди любви часто преподносятся и воспринимаются как «рядовые». Их, так сказать, через запятую называют в проповедях среди других христианских добродетелей - смирения, терпения, поиска правды и т. д. Любовь же - не одна из заповедей, а определитель всей христианской жизни! И это должно сочиться через все поры христианской Церкви. «По тому узнают все, что вы Мои ученики, если будете иметь любовь между собою» (Ин. 13:35) - говорит Господь будущим Апостолам.

Именно любви - а значит, доброты, милосердия, гуманности, терпения, отсутствия всякой ненависти к «чужакам» - не очень чувствуется ни среди паствы, ни среди пастырей. И хотя в храмовых проповедях священники постоянно напоминают о необходимости любви к ближнему, это не проникает в сердца многих людей. Во-первых, потому, что эта главная заповедь как бы растворяется среди множества христианских обязанностей и запретов. И тогда, в силу огромной трудности исполнения заповеди любви, иные, может, даже не отдавая себе отчет в этом, полагают, что можно, так сказать, компенсировать недостаток любви более ревностным исполнением обрядов и самоограничениями. А во-вторых, люди имеют перед собой очень мало сегодняшних примеров подлинно христианского отношения к ближнему в самой соборной Церкви.

Началось это не сегодня, но к настоящему времени постепенно создался образ Церкви, скорее, как охранительницы всего старинного, нежели исполнительницы зова Христова «Придите ко Мне все труждающиеся и обремененные, и Я успокою вас...» (Мф. 11:28). Разумеетя, тому есть свои причины - и ереси, и посягательства на церковные дела со стороны светских властей, и попытки увести паству в лоно иных религий, и многое другое. Потому говорю об этом не в осуждение, а только в силу ощущения, что настало время для возвращения нашей христианской Церкви к тем непреложным истокам, которые возвестил нам Спаситель и на основе которых именно христианство смогло стать мировоззрением, определяющим лицо мира. И речь тут вовсе не о реформах в Церкви (автор просто не берется судить о их необходимости), а именно об изменении духа служения.

Как реализовать миссионерство через любовь - для этого нужна особая дискуссия, прежде всего внутри самой соборной Церкви. Понятно лишь, что на этом пути придется столкнуться с многими пре- 
дубеждениями, с укоренившимися в христианской среде стереотипами и даже предрассудками. К чему и следует относиться без терпимости, так это к проявлениям ненависти к людям, ибо ненависть противна Богу.

Однако если понятие «любовь» весьма органично вписывается в рассуждения об институтах духовных, то может ли оно быть включено в ткань светской государственной (публичной) жизни? Полагаю, что при определенных условиях может (имею в виду главным образом российскую государственность).

Первое условие - официальный отказ от материализма в качестве мировоззрения, лежащего в основании права, и безусловное признание христианства как мировоззренческой и этической основы государственности. Христианства - не в религиозном, а именно в философском смысле.

Такую мировоззренческую самоидентификацию государство должно закрепить в своей конституции. Вслед за этим должны быть пересмотрены школьные и вузовские программы. А главное, писаная история должна включать в себя факты из истории, пока относящейся исключительно к истории духовной. Прежде всего достоянием светской исторической науки должны стать события, описанные в Священном Писании. Но описанные с учетом того, что люди будут иметь дело с учебником истории, а не с Законом Божиим. Для включения же самого Закона Божия в число обязательных учебных дисциплин должна появиться реальная общественная потребность. В противном случае он станет предметом, который не только не достигнет своей цели духовного просвещения, но, наоборот, уведет многих от того прекрасного и возвышающего душу, что несет христианство.

Вообще процесс пронизывания государственности христианскими принципами не должен быть поспешным, тем более своеобразной кампанией. Ему обязательно должны предшествовать общественные и научные дискуссии, как наилучшим образом, с какой последовательностью он должен протекать, а также фундаментальные и прикладные работы. Упаси нас Бог, если за преобразование общества на идеалистический лад возьмутся чиновники.

Речь, вновь повторю, не идет об установлении теократии или о

43 Окончательное решение о признании той или иной организации тоталитарной $u$, соответственно, о ее запрете, разумеется, должсно приниматься судом. Но таким судом, который будет иметь впол-

не определенную мировоззренческую осHOBY. привилегированном положении христианской Церкви, о ее вмешательстве в государственные дела. Главное - это не нужно и даже вредно для самой Церкви, этого не требует от нас Христос. Церковь должна быть отделена от государства. Губительно отделять от государства христианскую мораль! Вот почему речь идет по-прежнему о светском государстве, но официально признающем Небесный причинный принцип. В таком государстве все религиозные организации (кроме, разумеется, исповедующих сатанистские и иные тоталитарные культы ${ }^{43}$ ) должны быть равноправны в их взаимоотношениях с государством. Здесь не ликвидируются ни свобода совести, ни принцип отделения церкви от государства, но открыто провозглашается, что конституционный строй 
и правовая система основаны и действуют на тех императивах и ограничениях, которые вытекают из христианского учения.

Одно из главных возражений, которое можно предвидеть, состоит в указании на противоречие между понятиями "светское государство» и «христианские принципы». Но есть ли тут противоречие? Ведь я не случайно так много места отвел попытке обосновать идею о том, что христианство - не только религия, но и вполне определенное мировоззрение, вполне определенная этическая система. Поэтому в моей м0дели не предлагается выбирать между светским государством и теократией; не предлагается устанавливать государственную (обязательную) религию; не предлагается делить людей в зависимости от их отношения к Небу. И вообще такая государственная модель совершенно не означает, что христиане собираются под себя переделывать государство, делать его удобным для себя, создавать себе привилегии, а того пуще, с помощью власти бороться с иными верованиями.

Если же кто-то возразит, что, мол, такая государственность есть разновидность тоталитарной, один из признаков которой - монополия на единственную идеологию, то вновь напомню, что говорилось выше: все государства современного мира в любом случае зиждутся на определенной ценностной системе и в своих писаных или неписаных конституциях закрепляют ее и не позволяют, хотя бы формально, выходить за рамки такой определенной системы, будь то демократия, теократия и проч. Так что христианская государственность отнюдь не есть тоталитаризм, ибо в отличие от последнего, не предполагает всеобщего контроля за гражданами по поводу того, оказывают ли они знаки почтения Богу, ходят ли в храмы, как регулярно и т. п. Для иллюстрации можно сказать 0 православной и в то же время демократической Греции, тексту Конституции которой предшествуют слова: «Во имя Святой, Единосущной и Нераздельной Троицы», а в ст. 3 прямо провозглашается: «Господствующей в Греции религией является религия восточно-православной Церкви Христовой». Можно в этом ряду назвать и Конституцию Норвежского Королевства, где в 22 сказано о том, что «все жители государства обладают свободой религиозной совести» и в то же время - что «Евангелическо-лютеранская религия является официальной государственной религией». Но кто скажет, что Норвегия не является демократическим государством?

Тогда где те правовые аргументы, по которым христианскому мировоззрению следует отказать в возможности быть ценностной основой государственности? Их нет. Наоборот, актуальны аргументы, по которым государственные правила, пронизанные христианскими принципами, должны стать ценностной основой, ибо такие правила единственно и могут сберечь правовую государственность от разложения и распада.

Конечно, есть еще один существенный вопрос, который все время будет возникать и который обойти невозможно. Как быть, когда в традиционно христианских государствах существуют довольно много- 
численные группы людей, исповедующих ислам, иудаизм, буддизм и проч.? Особенно этот вопрос актуален для России, где есть регионы, традиционно населенные гражданами, принадлежащими к нехристианским вероисповеданиям. Не воспримут ли они переход к христианской государственности как покушение на их гражданские и духовные свободы, на их самобытность, на их право исповедовать свою религию?

Для ответа не буду ссылаться, скажем, на страны, которые официально не стесняются своей традиционной цивилизационной принадлежности, будь то ислам (Саудовская Аравия), буддизм (Непал), иудаизм (Израиль) или христианство (та же Норвегия). Приведу другой аргумент. Речь совершенно не идет о навязывании гражданам постулатов одной религии. И дело не только в том, что христианство - принципиально антинасильственно и принципиально терпимо (нетерпимость, да и та ненасильственная, как это известно из житий святых мучеников, проявляется лишь тогда, когда самим христианам навязывают духовное предательство, заставляя поклоняться (чужим богам»). Дело в том, что предлагаемая организация публичной жизни вообще ни от кого не требует изменить свое верование или не быть атеистом. Повторю, свобода совести остается неприкосновенной. Все дело лишь в мировоззренческой идентификации данной государственности.

Такое государство не только не разрушает, но и безмерно укрепляет и свободу, и равноправие, и, главное, достоинство личности. Если человек не верит в Бога или исповедует веру в рамках иной религии, в христианском государстве это должно оставаться делом самого человека. Принципиальное отличие тут в другом - в том, что государство формирует определенный дух публичной жизни. Что же касается жизни духовной, то как раз публичная организация, основанная на христианских принципах, является главной гарантией религиозной свободы. Больше того, христианская самоидентификация России окажет благотворное влияние на регионы, имеющие статус государственных образований (субъектов РФ), с традиционным преобладанием нехристианского населения. Там станет возможно дополнение общегосударственных правил правилами, запретами, разрешениями, установленными местной доминирующей религией (но все при том же обязательном и универсальном условии уважения свободы и достоинства человека).

Второе условие - официальное провозглашение доктрины «госу-

14 Я сознательно избрал такую формулу, чтобы прямо противопоставить ее известной доктрине "государства всеобиего благоденствия». дарства всеобщего милосердия» ${ }^{44}$. Автор сознает все те ограничения, которые вытекают из природы власти и государственного организма (например, в отличие от человека, невозможно требовать от государства исполнения заповеди о любви к врагам). В то же время государство имеет все возможности заложить в праве такие критерии, которые задавали бы вполне определенные паттерны и для представителей государства, и для граждан. Такая модель, безусловно, потребует перестройки концепции внешнеполитических отношений, заставит по-иному подойти к проблемам культуры, экономики, распределения национального богатства. 
Секуляризм не в состоянии быть источником милосердной (в самом широком понимании этого слова) государственности. Максимум, на что способна государственность, основанная на секулярных принципах, оказывать некоторую социальную и правовую помощь «аутсайдерам). Идея секулярного социального вспомоществования берет начало в элементарном чувстве самосохранения сильных мира сего. На это опять скажут: «Неважно, какая идейная подкладка под таким поведением государства. Главное - результат». Нет! Огромное заблуждение, в глубине имеющее под собой презрение «к черни», полагать, будто «простые люди» не ощущают общего духа государственности. Ощущают! И потому практически нигде не испытывают благодарности к правительствам, даже в тех странах, где действуют эффективные социальные программы. Но даже не в этом дело. А в том, что от социальной помощи секулярное государство тут же готово отказаться, как только на горизонте замаячит очередная глобальная угроза (пробные шаги в этом направлении уже делаются в разных странах).

В государстве всеобщего милосердия одним из главных должен быть принцип: «Слабый имеет преимущество». Речь идет о философии, которой будет пронизана вся государственная политика и которая сделает человечнее всю жизнь в стране, сделает человечнее саму страну. Имею в виду не призывы к совести, к проявлению такта, благородства, милосердия. В конце концов, каждый человек сам для себя решает, каким он хочет предстать в глазах людей и перед Богом. Но государство может создать такие правовые нормы, которые, становясь стереотипами, формируют иной стиль взаимоотношений в обществе. Если в древней Спарте от слабых и немощных избавлялись, не видя в них «практического смысла», то христианское государство, наоборот, должно сверять обцую "скорость развития» не по "скорости лидеров», а по "скорости слабых" (здесь понадобятся новые критерии оценки социально-экономического положения страны и соответствующая им политика). Возможно, при этом мы потеряем в эффективности. Но тогда спросим себя - эффективность ли является нашей целью или есть вещи поважнее? И не будет ли сегодняшняя потеря в эффективности завтрашним общенациональным выигрышем?

В то же время понятно, что у государства должно быть достаточно материальных средств для проведения такой философии в жизнь. Следовательно, необходимо обеспечить самые благоприятные условия для самореализации экономически активной части общества. Однако одновременно государство обязано формировать и поощрять принцип: «Богатство - обязывает». Достичь реализации этого принципа не удастся за короткое время. Скорее всего, потребуется смена поколений. Но в силах общества и государства - постепенно провести переоценку ценностей, переоценку самого понятия «успешность». Это - труднейшая задача. Но ее решение реально при последовательном проведении соответствующей политики, формировании соответствующих образцов с0циального поведения. 
Третье условие - пронизывание сферы властной деятельности христианским принципом «Больший да будет вам слугою». Другими словами, речь идет об ответственности начальствующих. Еще царь Соломон говорил: «Итак, слуиайте, чари, и разумейте, научитесь, судьи концов земли! Внимайте, обладатели множества и гордяииеся пред народами! От Господа дана вам держава, и сила - от Вышнего, Который исследует ваши дела и испытает намерения. Ибо вы, будучи служителями Его иарства, не судили справедливо, не соблюдали закона и не поступали по воле Божией» (Прем. 6:1-4).

Нельзя, конечно, строить государственность на презумпции того, что государственные чиновники пропустят через свой ум и сердце свою высокую духовную ответственность, проникнутся духом служения. Поэтому названный принцип должен пронизывать соответствующие правовые нормы. Этим не ликвидируется вечное противоречие между ответственным властвованием и упоением властью. Но, пойдя в таком направлении, появится возможность хотя бы сглаживать остроту такого противоречия.

Четвертое условие - восприятие обществом и государством (через определенные институциональные изменения) одной из Христовых заповедей блаженства, а именно: «Блаженны миротворцы». Этими словами из Нагорной проповеди я бы обозначил принцип, в соответствии с которым система принятия общегосударственных (а равно региональных и местных) решений порождает не внутреннее (а за ним порой и внешнее) сопротивление тех, кто не согласен с тем или иным решением, а, наоборот, примиряет, соединяет общество. Миротворческая суть этого принципа заключается в том, что благодаря ему:

- понятие «большинство» не означает единовластия и, соответственно, «меньшинство» не означает маргинальности;

- общество договаривается лишь о том, какие идеи и ценности оно не принимает ни под каким видом, и конституционно закрепляет эту позицию. Все иные легально представленные ценности и мнения не отсекаются, а учитываются при выработке решений;

- в государственном организме предусматривается институт авторитетного хранителя общественного спокойствия, который, сам не участвуя в повседневной политической жизни, является инструментом вывода из политических тупиков в силу самой его роли, миссии.

Здесь названы далеко не все условия, требующиеся для преображения духа государственности. Собственно, формулирование этих условий и наполнение их содержания конкретными мерами - отдельная задача. 